\title{
EFFECTS OF PHOSPHORUS FERTILIZATION ON ARSENIC UPTAKE BY WHEAT GROWN IN POLLUTED SOILS
}

\author{
M. Pigna ${ }^{1}$, V. Cozzolino ${ }^{1}$, A. Giandonato Caporale ${ }^{1}$, M.L. Mora ${ }^{2}$, V. Di Meo ${ }^{1}$, \\ A.A. Jara ${ }^{2}$, and A.Violante ${ }^{1}$
}

${ }^{1}$ Dipartimento di Scienze del Suolo, della Pianta e dell'Ambiente, Università di Napoli Federico II, Napoli, Italy. ${ }^{2}$ Departamento de Ciencias Químicas y Recursos Naturales, and Scientific and Technological Bioresource Nucleus (BIOREN-UFRO), Universidad de La Frontera, Temuco, Chile. *Corresponding author: massimo.pigna@,unina.it

\begin{abstract}
In this study we have examinated the results of two experiments on the uptake and distribution of arsenic (As) in roots, shoots, and grain of wheat grown in As-polluted soils and in an unpolluted soil irrigated with As-contaminated water in absence or presence of phosphorus (P) fertilization. Arsenic concentrations in wheat samples of the two experiments are higher than those in the plants grown on uncontaminated soil. In the experiments showed in this work, it is highlighted the role of $\mathrm{P}$ fertilization in preventing As uptake and translocation in wheat plants. These findings could have important implications to reduce the potential risk posed to human health by As entering the food-chain.
\end{abstract}

Keywords: phosphorus fertilization, arsenic, wheat, polluted soils.

\section{INTRODUCTION}

There is increasing concern worldwide regarding the contamination of soil with arsenic (As), and the potential risk to human and environmental health arising from such contamination (Smith et al., 1998). Arsenic contamination of soil can occur as a result of both natural sources and anthropic activities, including the use of arsenical pesticides and herbicides, atmospheric deposition, mining activity, waste disposal, and other sources (Mandal and Suzuky, 2002). Furthermore, in spite of the low geochemical abundance of As (average earth crust $1.8 \mathrm{mg} \mathrm{kg}^{-1}$ ) some degree of arsenic dissolution might cause critical value is only $10 \mu \mathrm{g} \mathrm{L}^{-1}$. High concentrations of As in groundwater has been reported from several countries including Argentina, Bangladesh, Chile, China, Hungary, Mexico, West Bengal (India), and Vietnam (Smith et al., 1998). New cases of high concentrations in drinking water have been reported when As analyses was included in routine water analysis. These cases included some areas of Italy where elevated as concentrations in groundwater and in soils were recently found (Costagliola et al., 2004).

Typical uncontaminated agricultural soils contain 1-20 mg kg-1 (Wauchope, 1983), but contaminated soils in mining or industrial areas contain levels as high as $45-2600 \mathrm{mg} \mathrm{kg}^{-1}$ (Brandsetter et al., 2002). In many cases, extensive use of As-rich groundwater has led to elevated As concentrations in agricultural soils, 
which may reduce soil productivity, be toxic to plants, and enter into the crops (Heikens, 2006. Martin et al., 2007). In fact, As is not an essential element for plants, but interferes with plant metabolism, inhibiting plant growth and crop yield (Barrachina et al., 1995; Abedin et al., 2002; Rahman et al., 2004). Therefore, minimizing soil-plant transfer of As is essential for agriculture on Asaffected farmland.

In contrast, phosphorus $(\mathrm{P})$, that is a chemical analogue of As (Adriano, 2001) and competes with As in plant uptake (Meharg and Macnair, 1992), is one of 17 essential elements required for plant growth (Raghothama, 1999), and often the overriding nutritional limitation in modern cereal farming (Runge-Metzger, 1995). It is estimated that crop yields on around $30-40 \%$ of the world's arable land are limited by $\mathrm{P}$ availability (RungeMetzger, 1995). The effect of $\mathrm{P}$ on the sorption/desorption of As in soil environments has received great attention, especially when $\mathrm{P}$ is used as a crop fertilizer (Peryea, 1998). The bioavailable fraction of As in soils to crop plants depends on different physical and chemical properties of soils. In fact soils rich in variable charge minerals ( $\mathrm{Al}$ or $\mathrm{Fe}$ oxides) do not release As easily. Only large additions of $\mathrm{P}$ to high anion-fixing soils or alkaline $\mathrm{pH}$ or $\mathrm{Fe}$ and $\mathrm{Al}$ oxide dissolution may affect As solubility (Smith et al., 1998; Violante and Pigna, 2002). However, As sensitivity is intimately linked to $\mathrm{P}$ nutrition in plants. In rice seedlings, even cultivars found to be susceptible to arsenate can become more resistant by raising level of intracellular P (Geng et al., 2006; Wang and Duan, 2009). Gultz et al. (2005) reported that $\mathrm{P}$ availability and $\mathrm{P}$ demand, which are plant specific, have to be taken in account to predict uptake of As by crop plants. Therefore, As toxicity in crops can be more prevalent in situation where As contamination is found coexisting with low available $P$.

Much of the research on As in grain crops have focused on rice (Oryza sativa L.) (Abedin et al., 2002; Williams et al., 2005; Rahman et al., 2007). The work that has been conducted on wheat is less extensive (Tao et al., 2006; Zhao et al., 2007), with limited information regarding soil-root, root-shoot and shoot-grain assimilation and translocation (Williams et al., 2007). In Tuscany, Italy there is extensive soil contamination with As due to base mining and processing activities (Costagliola et al., 2004). Elevated As concentrations have been reported for Scarlino, close to Grosseto, in southwest Tuscany (ARPAT-UNIFI, 2003). Wheat ( $T$. durum) is the main crop cultivated in this area. Grain is largely used for human consumption and as poultry feed. Also, the straw is used as fodder for cattle. The aim of this work was to evaluate the role of $\mathrm{P}$ fertilization on growth, As uptake and partitioning between different plant part (grain, shoot, root) in wheat $(T$. durum). In one experiment wheat was grown in two contaminated soils (Vetricella and La Botte) and in an uncontaminated soil (Padula) collected from Scarlino. The second experiment examined the effect of $\mathrm{P}$ fertilization on wheat grown in an uncontaminated soil, collected from a natural grass in Presenzano, Caserta, Italy, and irrigated with solutions containing As at three different concentrations.

\section{MATERIALS AND METHODS}

Some physical and chemical properties of the soils utilized in these experiments are presented in Table 1. The analyses were carried out as reported in previous works (Cozzolino et al., 2010; Pigna et al., 2009). A five-step sequential extraction 
procedure for As (Wenzel et al., 2001) was performed on contaminated soils (Table 1). The first extraction step (Step 1), performed with $0.05 \mathrm{M}\left(\mathrm{NH}_{4}\right)_{2} \mathrm{SO}_{4}$, represents the most labile As of the procedure. The second extraction (Step 2), with $0.05 \mathrm{M} \mathrm{NH}_{4} \mathrm{H}_{2} \mathrm{PO}_{4}$, was used to assess the As fraction that can be specifically replaced by phosphate. Even if not as easily released as the first fraction, this one can also be considered as labile As. The following steps included extractions with $0.2 \mathrm{M}$ ammonium oxalate at $\mathrm{pH} 3$, in the dark (Step 3); with ammonium oxalate and ascorbic acid, in the light (Step 4); and an acid digestion with $\mathrm{HNO}_{3}$ 65\% and $\mathrm{HF}$ 50\% (Step 5). These three final fractions, representing As bonded to amorphous (Step 3) and crystalline (Step 4) hydrous oxides of Fe and $\mathrm{Al}$, and residual As (Step 5), can be considered as nonlabile As. The sequential extraction was carried out in triplicate on $1 \mathrm{~g}$ of soil in $50-\mathrm{ml}$ polypropylene centrifuge tubes to facilitate washing of the soil after each extraction thus minimizing any loss of the solids. The supernatants were separated by centrifugation (1700g) and filtered through $0.45-\mu \mathrm{m}$ filters. The total soil arsenic concentration was determined by digesting the soils with concentrated $\mathrm{HNO}_{3}$ and $\mathrm{HF}$ at 5:1 ratio. Total As concentrations of soil extracts and digests were determined by hydride generationinductively coupled plasma spectrometry (HG-ICP - AES, Varian, Liberty 150).

Experiment 1. Vegetative responses of wheat grown on contaminated soils and uncontaminated soil with and without additional $\mathbf{P}$

Experiments were conducted for seven months in an unheated greenhouse. Series of twelve pots were filled with $7 \mathrm{~kg}$ of each of the three soils with different arsenic content. Wheat (T. durum cv Creso) plants were sown directly in pots at a density of 10 seeds per pot. Fourteen days after sowing the seedlings were thinned to 3 plants per pot. All the pots were fertilized every 2 weeks with $80 \mathrm{~mL}$ of nutrient solution containing $29.1 \mathrm{mM}$ $\mathrm{N}$ as $\mathrm{NH}_{4} \mathrm{NO}_{3}$ and $25 \mathrm{mM} \mathrm{K}$ as $\mathrm{K}_{2} \mathrm{SO}_{4}$. One third of the pots did not receive any phosphorus in the nutrient solution (P0 treatment); another third of the pots received $2.8 \mathrm{mM} \quad \mathrm{P}$ as $\mathrm{K}_{2} \mathrm{HPO}_{4}$, corresponding to a fertilizer distribution of $75 \mathrm{~kg} \mathrm{ha}^{-1}$ of P (P1 treatment); the last third of the pots received 5.6 mM P (150 $\mathrm{kg} \mathrm{ha}^{-1}$ ) included in the nutrient solution (P2 treatment). Thus, each of the three thesis with soils at different As content received three $\mathrm{P}$ treatments, and each treatment was replicated 4 times to give a total of 36 pots. The design was completely randomized and re-arranged every day.

\section{Experiment 2. Vegetative responses of wheat grown on an uncontaminated soil and irrigated with water containing As at three different concentrations, with and without additional $P$}

The wheat plants were grown for seven months in an unheated greenhouse. Wheat (Triticum durum cv. Creso) plants were grown in pots filled with $7 \mathrm{~kg}$ of the soil planted at a density of 10 seeds per pot, sown directly in the pots, and irrigated during the first 2 weeks with water. After this period the seedlings were thinned to 3 per pot, and were irrigated with water containing arsenate $\left(\mathrm{Na}_{2} \mathrm{HAsO}_{4}\right)$ at four different concentrations: 0 (control treatment), $0.5,1$, and $2 \mathrm{mg} \mathrm{L}^{-1}$ of As, until the wheat grain was ripe. The range of arsenate concentrations was chosen to encompass the concentrations occurring in underground waters of the As-affected areas of world. Contaminated water was 
Table 1. Selected physical and chemical properties of the soils in the two experiments.

\begin{tabular}{|c|c|c|c|c|c|c|c|}
\hline Soil & $\begin{array}{c}\mathbf{p H} \\
\left(\mathbf{H}_{2} \mathrm{O}\right)\end{array}$ & $\begin{array}{c}\text { Organic } \\
\text { matter }\end{array}$ & Sand & Silt & Clay & $\begin{array}{r}\mathbf{P}_{2} \mathbf{O}_{5} \\
\end{array}$ & As \\
\hline \multicolumn{8}{|c|}{ Experiment 1} \\
\hline Padula & 8.0 & 32.0 & 321 & 341 & 339 & 44.8 & 14 \\
\hline Vetricella & 6.7 & 16.0 & 482 & 270 & 248 & 20.3 & 192 \\
\hline La Botte & 8.1 & 40.0 & 293 & 365 & 342 & 16.9 & 304 \\
\hline \multicolumn{8}{|c|}{ Experiment 2} \\
\hline Presenzano & 5.70 & 23.0 & 131 & 388 & 275 & 13.5 & 6.8 \\
\hline
\end{tabular}

added as required to maintain moisture content at $60 \%$ of water holding capacity. All the pots were fertilized each 2 weeks with $80 \mathrm{~mL}$ of nutrient solution containing $29.1 \mathrm{mM} \mathrm{N}$ as $\mathrm{NH}_{4} \mathrm{NO}_{3}$ and 25 $\mathrm{mM} \mathrm{K}$ as $\mathrm{K}_{2} \mathrm{SO}_{4}$. Furthermore, in half of the pots $5.6 \mathrm{mM} \mathrm{P}$ as $\mathrm{K}_{2} \mathrm{HPO}_{4}$ was included in the nutrient solution in order to evaluate the influence of Phosphorus on As uptake by plants. Thus, there were 2 treatments without supplemental $\mathrm{P}(\mathrm{P}-)$ and with supplemental $\mathrm{P}(\mathrm{P}+)$. The design was completely randomized and rearranged every day, and each treatment was replicated 4 times to give a total of 32 pots. As irrigation was stopped 1 week before harvest.

Contemporaneously, a germination assay was carried out. Thirty surfacesterilized seeds of wheat were placed on a filter paper, collocated on a Petri plate, moistened with aqueous solution of arsenate at four concentrations $(0,0.5$,

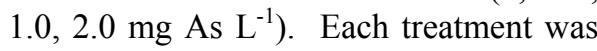
replicated four times. The seeds were incubated in dark at $24^{\circ} \mathrm{C}$. Germinated seeds were counted 5 days after initiation.

\section{Plant harvest and analysis}

Seven months after sowing, wheat plants were harvested by cutting the stem $3-4 \mathrm{~cm}$ above the soil. Wheat spikes were collected and dried at $70^{\circ} \mathrm{C}$ to constant weight. The spikes were then dehusked by hand and the weight of the grain was recorded for each pot. Shoots and roots were washed with tap water and then rinsed twice with deionized water. The dry weights of the roots and shoots were determined after oven drying at $70^{\circ} \mathrm{C}$ for 48 h. Roots, shoots, and grain were analyzed for total concentration of As. All samples were ground using a PM 200 ball mill (Retsch) and were digested in a microwave (Milestone, Digestor/Dring Ethos 900). A sample of about $0.5 \mathrm{~g}$ was accurately weighted into a PTFE pressure vessel and $7 \mathrm{~mL}$ of $\mathrm{HNO}_{3}(65 \%), 0.5 \mathrm{~mL}$ of $\mathrm{HF}(50 \%)$, and $2 \mathrm{~mL}$ of $\mathrm{H}_{2} \mathrm{O}_{2}$ were added. All glassware and plasticware were previously acid-washed with $3 \mathrm{M}$ $\mathrm{HCl}$, and rinsed with deionized water. Arsenic concentrations in roots, shoots and grain were determined by flowinjection hydride generation atomic absorption spectrometer using a PerkinElmer AAnalist 700 interfaced with a FIAS 100 hydride generator. Hydride generation was used for roots, shoots and grain samples due to the lower detection limits of this technique $\left(0.5 \mu \mathrm{g} \mathrm{L}^{-1}\right)$. All analyses were carried out in triplicate. In each analytical batch at least, one reagent blank and one internationally certified reference material (CRM), oriental 
tobacco leaves CTA-OTL-1, was included to assess precision and accuracy of the chemical analysis.

\section{Statistical analysis}

Data analyses were performed with Kaleidagraph 3.6. Treatment effects were determined by analysis of variance. Differences were considered as statistically significant at $p<0.05$ (Tukey's test).

\section{RESULTS AND DISCUSSION}

Experiment 1. Vegetative responses of wheat grown on two contaminated soils and on an uncontaminated soil with and without additional $P$

\section{Plant growth and As toxicity}

The soils investigated in this study originated from sites where As contamination was due to high As content in the geological materials and to mining and industrial activities (Donati et al., 2005). The total As concentrations in the two polluted soils were clearly higher than Italian regulatory limits of As contamination in agricultural soils $(20 \mathrm{mg}$ $\mathrm{kg}^{-1}$ ) (DM 471/99). The highest As concentrations was observed in La Botte soil (304 mg kg-1) (Table 1).

It was observed that plant biomass decreased markedly with increasing As concentration in soils (Table 3). For plants grown without $\mathrm{P}$ addition (P0 treatment) there was a decrease in biomass production of $11 \%, 58 \%$, and $60 \%$ compared to the plants that received P1 fertilization and of $16 \%, 65 \%$, and $69 \%$ with respect to the plants with $\mathrm{P} 2$ fertilization (Table 3), in Padula, Vetricella and La Botte soils, respectively. These findings are comparable to results reported for rice (Abedin et al., 2002) and wheat (Liu et al., 2005). Root biomass decreased significantly $(p<0.001)$ with increasing concentration of As in soils. In P0 plant series, it decreased by $72 \%$, and $83.6 \%$, respectively in Vetricella and La Botte, compared to plants grown in unpolluted soil. Phosphorus application significantly increased root biomass in all soils and treatments, ameliorating the toxic effects of As in these soils. The interaction between As and $\mathrm{P}$ on the growth response was significant in shoots. The shoot biomass (shoot plus leaf biomass) decreased with increasing concentration of As in soils, especially in the P0 plants (Table 2), but $\mathrm{P}$ addition, both in $\mathrm{P} 1$ and P2 treatments, ameliorated the effects of As.

The grain yield of wheat was greatly affected by the application of $\mathrm{P}$, ranging from 24.5 to $12.4 \mathrm{~g} \mathrm{pot}^{-1}$ for the P2 treatment; from 23.6 to $8.6 \mathrm{~g} \mathrm{pot}^{-1}, \mathrm{P} 1$ treatment; 21.20 to $2.10 \mathrm{~g}$ pot $^{-1}, \mathrm{P} 0$ treatment (Table 2). For the non contaminated soil (Padula), the difference between P2 and P0 treatment was lower (14\%) than for the two polluted soil, especially La Botte soil, where the increases in grain yield with respect with P0 treatment were $76 \%$ for P1 treatment and $84 \%$ for P2 treatment. According to our results, root biomass production responded more strongly to increasing soil As concentration compared to the shoot, especially in $\mathrm{P} 0$ plants. In the experiments reported here, in the presence of P supply, high As concentrations in the soils determined a moderate inhibition in wheat growth, including grain yield, especially at the highest $\mathrm{P}$ supply, compared to wheat growth in P0 treatment. Phosphorus has a protective effect with respect to As toxicity in wheat plant, particularly in La Botte soil, characterized by low P availability (Table 1). Studies on As toxicity have shown that 
Table 2. Fractionation of arsenic in polluted soils (Vetricella, La Botte)

\begin{tabular}{ccccccccc}
\hline Soil & $\begin{array}{c}\text { Step 1 } \\
\text { F1 }\end{array}$ & $\begin{array}{c}\text { Step 2 } \\
\text { F2 }\end{array}$ & $\begin{array}{c}\text { Step 3 } \\
\text { F3 }\end{array}$ & $\begin{array}{c}\text { Step 4 } \\
\text { F4 }\end{array}$ & $\begin{array}{c}\text { Step 5 } \\
\text { F5 }\end{array}$ & $\Sigma$ Steps & Total & $\begin{array}{c}\text { \% } \\
\text { recovery }\end{array}$ \\
\cline { 2 - 6 } & & \multicolumn{7}{c}{ As $\left(\mathrm{mg} \mathrm{kg}^{-1}\right)$} \\
Padula & - & - & - & - & - & - & 14.0 & - \\
Vetricella & 0.1 & 12.6 & 32.2 & 107.5 & 19.7 & 184.0 & 192.0 & 95.8 \\
La Botte & 0.4 & 30.7 & 93.5 & 140.7 & 10.6 & 275.9 & 304.0 & 90.7 \\
& & & & & & & & \\
\hline
\end{tabular}

Table 3. Root, shoot, grain, total biomass in a wheat (Triticum durum cv. Creso) grown in unpolluted (Padula) and polluted (Vetricella, La Botte) soils at three levels of $\mathrm{P}$ fertilization.

\begin{tabular}{|c|c|c|c|c|}
\hline \multirow[b]{3}{*}{ P0 treatment } & Root & Shoot & Grain & Total \\
\hline & \multicolumn{4}{|c|}{$\mathrm{g} \mathrm{pot}^{-1}$} \\
\hline & & & & \\
\hline Padula & $2.20 \pm 0.10 b$ & $12.80 \pm 0.60 \mathrm{bc}$ & $21.20 \pm 1.20 \mathrm{~b}$ & 36.20 \\
\hline Vetricella & $0.60 \pm 0.05 f$ & $6.50 \pm 0.40 f$ & $3.00 \pm 0.20 \mathrm{f}$ & 10.10 \\
\hline La Botte & $0.36 \pm 0.04 \mathrm{f}$ & $4.20 \pm 0.20 \mathrm{~g}$ & $2.10 \pm 0.10 \mathrm{f}$ & 6.66 \\
\hline \multicolumn{5}{|l|}{ P1 treatment } \\
\hline Padula & $2.60 \pm 0.20 \mathrm{a}$ & $14.40 \pm 1.05 \mathrm{ab}$ & $23.60 \pm 1.00 \mathrm{a}$ & 40.60 \\
\hline Vetricella & $1.40 \pm 0.10 \mathrm{~cd}$ & $9.60 \pm 0.60 \mathrm{de}$ & $13.20 \pm 0.73 \mathrm{~cd}$ & 24.20 \\
\hline La Botte & $1.00 \pm 0.10 \mathrm{e}$ & $6.90 \pm 0.55 f$ & $8.60 \pm 0.45 \mathrm{e}$ & 16.50 \\
\hline \multicolumn{5}{|l|}{ P2 treatment } \\
\hline Padula & $2.80 \pm 0.20 \mathrm{a}$ & $15.80 \pm 1.30 \mathrm{a}$ & $24.50 \pm 1.20 \mathrm{a}$ & 43.10 \\
\hline Vetricella & $1.70 \pm 0.10 \mathrm{c}$ & $11.00 \pm 0.50 \mathrm{~cd}$ & $16.00 \pm 0.82 \mathrm{c}$ & 28.70 \\
\hline La Botte & $1.20 \pm 0.10 \mathrm{de}$ & $8.20 \pm 0.40 \mathrm{ef}$ & $12.40 \pm 0.50 \mathrm{de}$ & 21.80 \\
\hline Site & $p<0.0001$ & $p<0.0001$ & $p<0.0001$ & \\
\hline P fertilization & $p<0.0001$ & $p<0.0001$ & $p<0.0001$ & \\
\hline Interaction & $p<0.05$ & $p<0.001$ & $p<0.0001$ & \\
\hline
\end{tabular}

root biomass decreased significantly $(p<$ 0.001 ) with increasing concentration of As in soils. In P0 plant series, it decreased by $72 \%$, and $83.6 \%$, respectively in Vetricella and La Botte, compared to plants grown in unpolluted soil. $\mathrm{P}_{\mathrm{i}}$ application significantly increased root biomass in all soils and treatments, ameliorating the toxic effects of As in these soils. The interaction between As and $\mathrm{P}$ on the growth response was significant in shoots. The shoot biomass 
(shoot plusleaf biomass) decreased with plant species not resistant to As suffer considerable stress upon exposure, with symptoms ranging from inhibition of root growth to plant death (Meharg and Macnair, 1991; Paliouris and Hutchinson, 1991; Barrachina et al., 1995). Arsenate acts as a phosphate (Pi) analogue and is transported across the plasma membrane via a Pi cotransport systems (UllrichErebius et al., 1989). Once inside the cytoplasm arsenate competes with $\mathrm{Pi}$, for example replacing $\mathrm{Pi}$ in ATP to form unstable ADP-As, leading to the disruption of energy flows in cells (Meharg, 1994). The effects of P nutrition on the mitigation of arsenate toxicity symptoms seem to be: 1) high plant $\mathrm{P}$ status leads to a down-regulation of the arsenate/Pi plasma-lemma transporters; 2) high cellular Pi levels results in greater competition with arsenate for biochemical processes where arsenate substitutes for Pi (Meharg, 2005).

Arsenic concentration and contents in wheat roots, shoots and grain

As concentration in wheat roots, shoots and grain increased significantly with the increase of total As concentrations in polluted soils and As concentrations of F1 and F2 fractions (labile fractions) (Figure 1). In fact, the total As and the sum of the F1 and F2 fractions were highly correlated with As root concentrations ( $\mathrm{r}$ $=0.976$ and $\mathrm{r}=0.897$, respectively) as well as with shoot $(\mathrm{r}=0.958$ and $\mathrm{r}=$ $0.745)$ and grain concentration $(r=0.870$ and $r=0.674)$ in P0 treatment. High correlation coefficients were found also for As bonded to amorphous (F3) and crystalline (F4) hydrous oxides of $\mathrm{Fe}$ and $\mathrm{Al}(\mathrm{r}=0.855$ and $\mathrm{r}=0.998$, respectively), but not for residual fractions. The results were almost the same in P1 and P2 treatments, although the correlation coefficients were lower. Arsenic concentration in the roots increased particularly in the P0 treatment. By increasing As concentration in the soils As root concentrations ranged from 0.28 to 3.50 in $\mathrm{P} 2$ plants and from 0.30 to 6.2 $\mathrm{mg}$ As $\mathrm{kg}^{-1}$ in P0 plants (Figure 1). Similar results were found in other studies investigating the influence of $\mathrm{P}$ on As accumulation by wheat (Tao et al., 2006).

Shoot As concentrations also rose with increasing As concentration in soil, more so for the P0 treatment. The highest shoot As concentration $\left(2.45 \mathrm{mg} \mathrm{kg}^{-1}\right)$ was measured in the plants grown in La Botte soil in the absence of $\mathrm{P}$ fertilization. Our results are in agreement with those reported in previous studies (Barrachina et al., 1995; Quaghebeur and Rengel, 2003). The ability of As to accumulate in wheat has already been shown. Greenhouse pot experiments on wheat grown in soil spiked with $50 \mathrm{mg} \mathrm{As} \mathrm{kg}^{-1}$ resulted in shoot levels of $\sim 3 \mathrm{mg} \mathrm{kg}^{-1}$ d.wt (Williams et al., 2007). In wheat grown in As-polluted soil (range 53.8-709 $\mathrm{mg} \mathrm{kg}^{-1}$ ), contaminated by the Aznalcollar mine spill, levels of $\sim 20 \mathrm{mg} \mathrm{As} \mathrm{kg}{ }^{-1}$ were detected in the shoots (Soriano and Fereres, 2003).

As concentration in grain in unpolluted soil (Padula) was only $\sim 0.03 \mathrm{mg} \mathrm{kg}^{-1}$ in all $\mathrm{P}$ treatments, increasing, in the most polluted soil (La Botte), to 0.62, 0.50, and $0.44 \mathrm{mg} \mathrm{kg}^{-1}$ in P0, P1, and P2 treatments respectively. These values are similar or slightly higher compared to those found by Williams et al., (2007) in wheat grain. They reported levels of $\sim 0.21 \mathrm{mg} \mathrm{kg}^{-1}$ in Scottish (East Coast) wheat grain, where the maximum soil As levels were of $18 \mathrm{mg} \mathrm{kg}^{-1}$, and of $0.50 \mathrm{mg} \mathrm{kg}{ }^{-1}$ in English (Cornwall and Devon counties) wheat grain, where the maximum As levels in soil was $201 \mathrm{mg} \mathrm{kg}^{-1}$. Greater As accumulation levels $\left(0.74 \mathrm{mg} \mathrm{kg}^{-1}\right)$ were observed in south-eastern Asia wheat (Norra et al., 2005), which was comparable to grain levels of $0.75,0.71$ and $0.69 \mathrm{mg} \mathrm{kg}^{-1}$ found in wheat grown in 

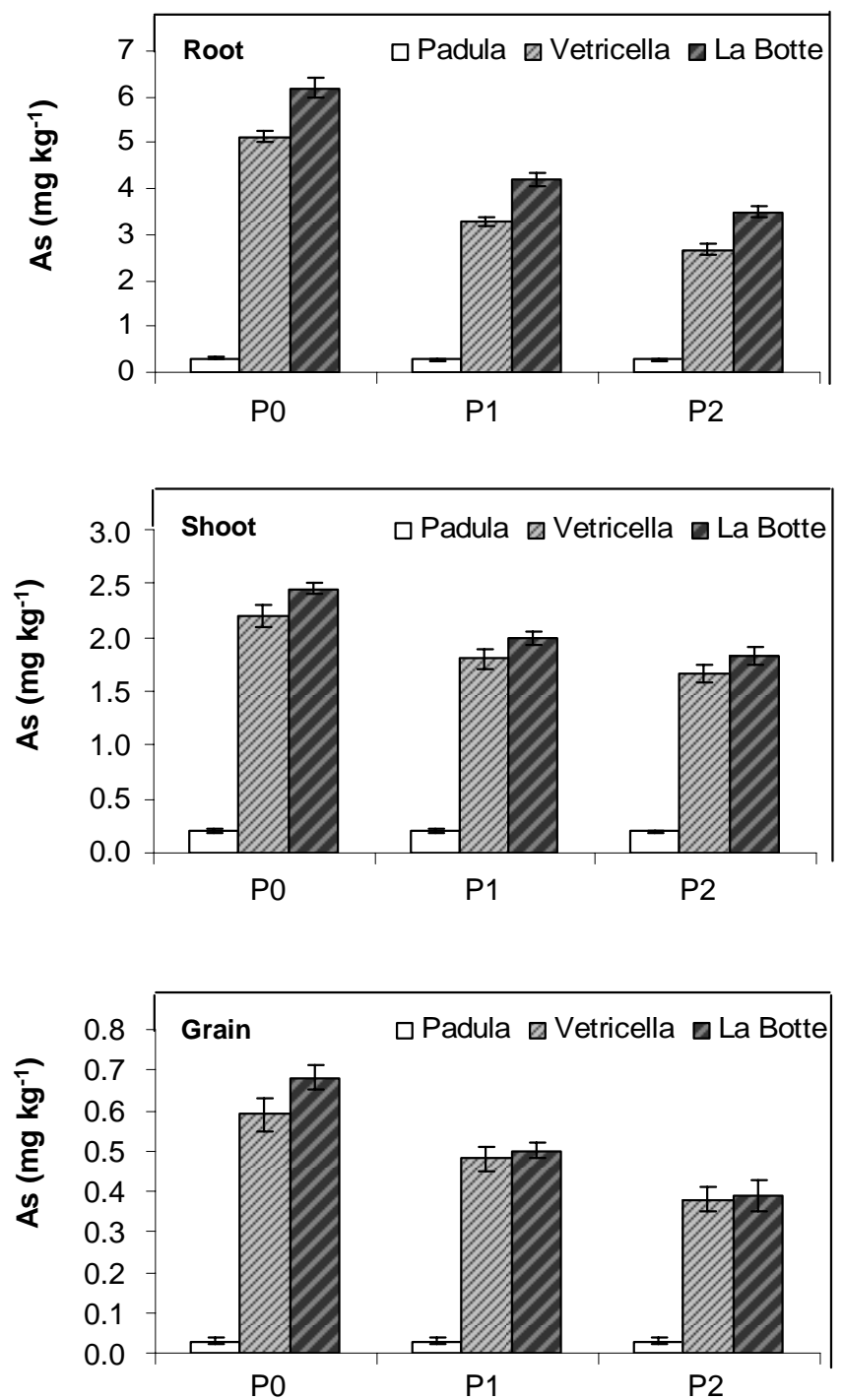

Figure 1. Total As concentration $\left(\mathrm{mg} \mathrm{kg}^{-1}\right)$ in roots, shoots, grain of wheat (Triticum durum cv. Creso) grown in unpolluted (Padula) and polluted (Vetricella, La Botte) soils at three levels of $P$ fertilization. Data are expressed as mean values $\pm S D(n=4)$ and have been analyzed by two-way analysis of variance. 
a greenhouse experiment in $50 \mathrm{mg} \mathrm{As} \mathrm{kg}{ }^{-1}$ spiked soil (Williams et al., 2007).

In the present study, although As was primarily bound with $\mathrm{Fe}$ and $\mathrm{Al}$ oxides (Table 1), plant growth was stunted in the two contaminated soils in absence of $\mathrm{P}$ addition, especially in the soil with the highest As concentrations in more labile soil fractions and with low $\mathrm{P}$ availability (See Table 1; Cozzolino et al., 2010). Phosphorus fertilization seems to reduce the effects of As toxicity, promoting plant growth without increasing As concentrations in above-ground parts of plants and limiting shoot to grain transfer, particularly at highest $\mathrm{P}$ level.

These observations corroborate the reports by Meharg (1994) that P restricted the transfer of As from soil to the aboveground plant organs. Also, $\mathrm{P}$ nutrition could be involved in the decrease in reactive oxygen species and non-protein thiols production, formed during exposure to As in the shoot that cause tissue damage and lipid peroxidation, affecting shoot-grain transfer. Geng et al., (2006), in two different genotypes of rice seedlings, found higher stress resulting from As exposure in genotype with higher overproduction of enzymatic antioxidants and non-protein thiols.

Experiment 2. Vegetative responses of wheat grown on uncontaminated soil irrigated with water containing As at three different concentrations, with and without additional $\mathbf{P}$

\section{Plant growth and As toxicity}

A downward trend was observed in plant growth with increasing As concentration in irrigation water (Table 4). For plants grown without $\mathrm{P}$ addition ( $\mathrm{P}-$ ) there was a decrease in biomass production of $15 \%$, $52 \%$, and $67 \%$ as As concentration in the irrigation water increased, with respect to control treatment. This reduction was less severe in the $\mathrm{P}+$ conditions, $12 \%, 16 \%$,

Table 4. Root, shoot, grain and total biomass in a wheat (Triticum durum cv. Creso) exposed to three arsenic concentration in irrigation water $\left(0.5,1.0\right.$, and $\left.2.0 \mathrm{mg} \mathrm{L}^{-1}\right)$.

\begin{tabular}{ccccc}
\hline As conc. mg L $^{-1}$ & Root & Shoot & Grain & Total \\
& & $(\mathrm{g})$ & \\
\hline Control P- & $1.80 \pm 0.06$ & $12.20 \pm 0.80$ & $8.40 \pm 0.45$ & 22.40 \\
0.5 & $0.83 \pm 0.05$ & $11.90 \pm 0.60$ & $5.75 \pm 0.22$ & 18.48 \\
1 & $0.57 \pm 0.03$ & $7.50 \pm 0.42$ & $3.00 \pm 0.18$ & 11.07 \\
2 & $0.38 \pm 0.03$ & $4.60 \pm 0.22$ & $2.20 \pm 0.12$ & 7.18 \\
& & & & \\
Control P+ & $2.40 \pm 0.16$ & $13.00 \pm 0.70$ & $21.25 \pm 1.05$ & 36.35 \\
0.5 & $2.30 \pm 0.14$ & $12.40 \pm 0.74$ & $17.60 \pm 0.90$ & 32.30 \\
1 & $1.95 \pm 0.10$ & $11.80 \pm 0.58$ & $16.90 \pm 0.88$ & 30.65 \\
2 & $1.60 \pm 0.12$ & $11.20 \pm 0.65$ & $14.30 \pm 0.62$ & 27.10 \\
& & & & \\
\hline
\end{tabular}

Values are expressed as mean \pm standard deviation with $n=4$ 
and 26\% respectively (Table 3 ). These findings are similar to results reported for rice (Abedin et al., 2002) and wheat (Liu et al., 2005).

Root biomass decreased significantly $(p<0.001)$ with increasing concentration of As in irrigation water. In P- plants, by $54 \%, 68 \%, 79 \%$ at $0.5,1,2 \mathrm{mg} \mathrm{As} \mathrm{L}^{-1}$ respectively, while by $4.2 \%, 19 \%, 33 \%$ in $\mathrm{P}+$ plants. $\mathrm{P}_{\mathrm{i}}$ application increased significantly root biomass in all treatment. Liu et al., (2005) reported a significant decline in root biomass production in wheat seedlings with the increase in arsenite and arsenate concentrations for all six varieties of Triticum aestivum studied. Quaghebeur and Rengel (2003), in the non tolerant species Holcus lanatus, found that at increasing As concentration in nutrient solution there was a decrease in the root and shoot dry weight, accentuated when the plants had no $\mathrm{P}$ supplied. Sneller et al. (1999) in hydroponic experiment did not observe any inhibition in root growth with up to concentrations of $0.58 \mathrm{mg}$ of $A s \mathrm{~L}^{-1}$ in high-P (3.1 mg L ${ }^{-1}$ ) treatment (on Silene vulgaris) but found $75 \%$ root growth inhibition in low $\mathrm{P} \quad\left(0.31 \mathrm{mg} \quad \mathrm{L}^{-1}\right)$ treatment. However, Abedin et al., (2002) observed no significant differences in rice root biomass as a result of $\mathrm{P}$ application.

The dry weight of shoots (shoot plus leaf biomass) was significantly influenced by the As X P interaction; the shoot biomass decreased with increasing concentration of As in irrigation water, especially in the P-plants. The grain yield of wheat (mass of grain pot $^{-1}$ ) was affected by the application of As in irrigation water. Grain yield was found to range significantly from 8.4 to $2.2 \mathrm{~g} \mathrm{pot}^{-1}$ from the control to the highest As level, in P- plants (Table 3), a decrease in yield of $74 \%$. While $\mathrm{P}+$ plants exposed to 0.5 and $2 \mathrm{mg} \mathrm{L} \mathrm{L}^{-1}$ showed little/or moderate decrease in grain yield (17 to $33 \%$ respectively) with weights ranging from
21.25 to $14.30 \mathrm{~g} \mathrm{pot}^{-1}$. At lower As application rates there was no effect on root/shoot ratios in $\mathrm{P}+$ plants, while at the lowest As treatment, a clear decrease of ratio was observed in P- plants (Table 3). It was demonstrated that root biomass responded more strongly to As application compared to the shoot, especially in P-plants.

In the experiments reported here, As concentrations of $0.5-2 \mathrm{mg} \mathrm{L}^{-1}$, had a moderate inhibition in plant growth, including grain yield, in the presence of $\mathrm{P}_{\mathrm{i}}$. The differences in mean biomass between $\mathrm{P}-$ and $\mathrm{P}+$ treatments at the higher As concentrations, also in these experiments, highlighted the role of $\mathrm{P}$ in preventing As toxicity and growth inhibition in wheat.

Arsenic concentration and contents in wheat roots, shoots and grain

Arsenic concentration in wheat root, shoot and grain, increased significantly with increasing As in irrigation water (Figure 2). Arsenic concentration in the roots increased particularly when $\mathrm{P}$ was added. By increasing As concentration in irrigation water from 0.5 to $2.0 \mathrm{mg} \mathrm{As} \mathrm{L^{-1 }}$ As root concentrations ranged from 0.63 to 2.06 and from 1.4 to $3.2 \mathrm{mg} \mathrm{As} \mathrm{kg}^{-1}$, respectively in $\mathrm{P}$ - and $\mathrm{P}+$ plants. Similar results were found in other studies (Tao et al., 2006), investigating the influence of $\mathrm{P}_{\mathrm{i}}$ on As accumulation by wheat.

Shoot As concentrations (mg kg-1) increased in plants irrigated with As contaminated water, but no significant difference were found at $0.5-1.0 \mathrm{mg} \mathrm{As}$ $\mathrm{L}^{-1}$ treatments and no difference were observed due to $\mathrm{P}_{\mathrm{i}}$ application. The highest shoot As concentration of $0.65 \mathrm{mg}$ $\mathrm{kg}^{-1}$ was measured in the highest As treatment. As concentration in grain at the control treatment was only $0.05 \mathrm{mg} \mathrm{kg} \mathrm{m}^{-1}$ which increased to $0.24 \mathrm{mg} \mathrm{kg}^{-1}$ at

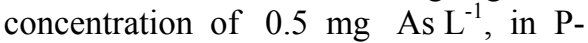



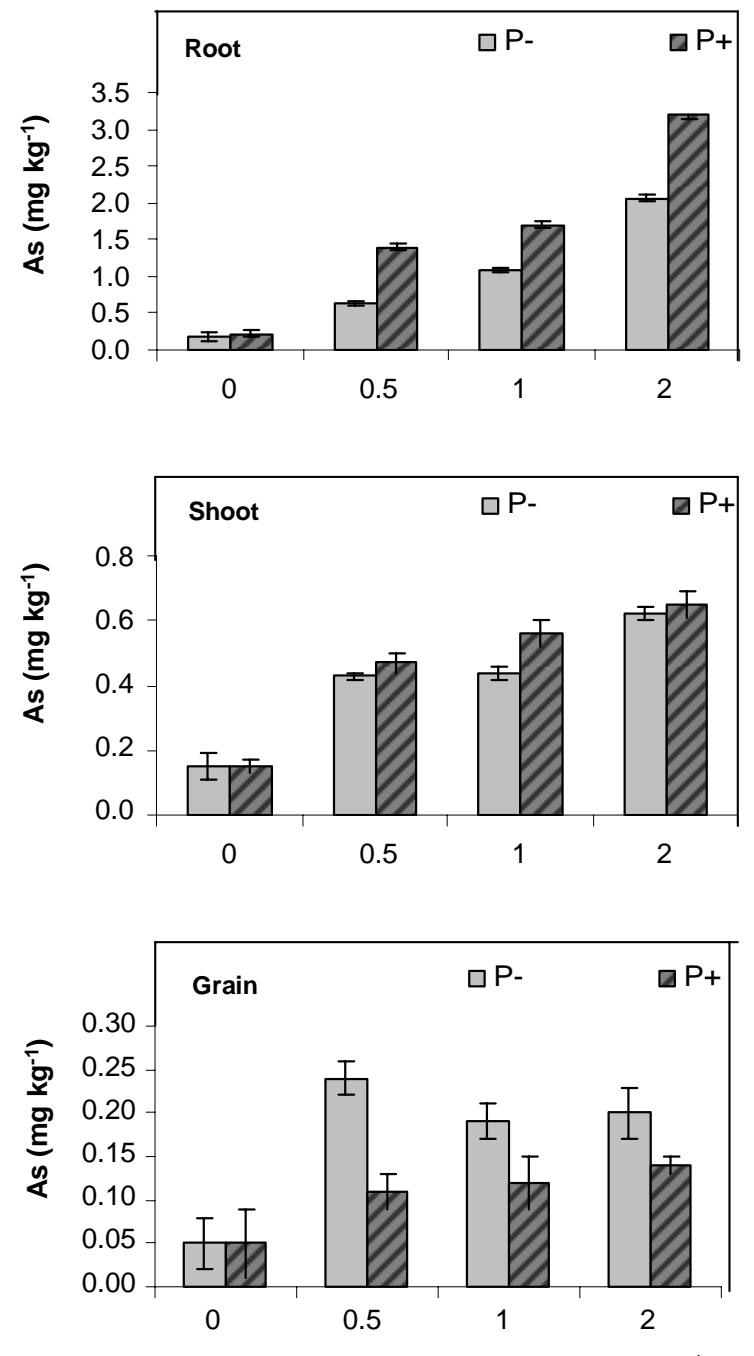

Figure 2. Total As concentration $\left(\mathrm{mg} \mathrm{kg}^{-1}\right)$ in roots, shoots, and grain of wheat (Triticum durum cv. Creso) exposed to three As concentration in irrigation water. Data are expressed as mean values $\pm \mathrm{SD}(\mathrm{n}=4)$ and have been analysed by two-way analysis of variance. 
plants, although remained constant for the next two arsenate treatments. In $\mathrm{P}+$ plants, grain As concentrations was found to range slightly from 0.05 to $0.14 \mathrm{mg}$ As $\mathrm{kg}^{-1}$ from the control to the highest As level (Figure 2). These results could indicate that at higher levels of As in irrigation water, the toxic element causes severe toxicity to wheat plant resulting in reduced growth rate and lowered translocation of As, as well as other nutrients from soil solution into the wheat grain. Similar results have been reported by Rahman et al. (2007) in rice plants and by Carbonell-Barrachina et al. (1997) in tomato and bean plants.

Figure 3 shows the As partitioning in wheat plant tissues. In P- plants for the highest As concentration in irrigation water As was found to be $72 \%$ in root, $21.5 \%$ in shoot and $6.5 \%$ in grain; whereas in $\mathrm{P}+$ plants, at the same As concentration, $81 \%$ was in the root, $15.5 \%$ in shoot and $3.5 \%$ in grain. Results indicate that regardless $\mathrm{P}$ treatment, most of the As accumulated in wheat plant tissues, remains in root and the smallest amount in the grain, although this behaviour was more pronounced in $\mathrm{P}+$ plants. In fact, $\mathrm{P}$ fertilization increased total As uptake (3.99 vs. $2.88 \mathrm{mg} \mathrm{kg}^{-1}$, see
Pigna et al., 2009), but the increase was restricted to the root. In rice plants, Abedin et al. (2002) also observed that a very large amount of As retained in root compared to its content in straw and grain. Other literature studies (Duxbury et al., 2002; Rahman et al., 2007) also reported similar results. CarbonellBarrachina et al. (1997) in a similar experiment, found that in tomato plants, $83,2 \%$ of all the adsorbed As remained in the root system, $16,8 \%$ in the shoots and only $7,3 \%$ reached the leaves, while in bean plants only accumulated $13,2 \%$ of the total plant As in the roots.

As allocation to the above ground portion of cereal crops is undesirable, as it will cause contamination of the human food-chain, with wheat being a staple in many countries around the globe. The results presented here indicate $\mathrm{P}$ supply may result in lower As allocation to the above ground (Figure 3), which has practical application in soil-crop systems. Other authors (Lu et al., 2010) indicated also that in rice, maintaining higher $\mathrm{P}$ concentration and $\mathrm{P} / \mathrm{As}$ molar ratio in rice shoot by variety breeding or soil management is one of the means for decreasing arsenic accumulation in rice grain.

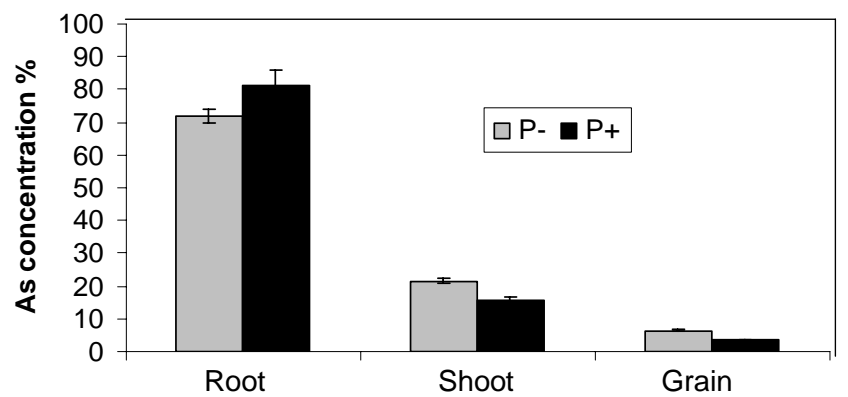

Figure 3. As partitioning (\%) in root, shoot and grain of wheat plants (Triticum durum

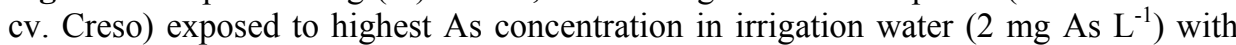
$(\mathrm{P}+)$ and without $(\mathrm{P}-) \mathrm{P}$ fertilization. Values are expressed as mean \pm standard deviation with $\mathrm{n}=4$. 
being a staple in many countries around the globe. The results presented here indicate $\mathrm{P}$ supply may result in lower As allocation to the above ground (Figure 3 ), which has practical application in soilcrop systems. Other authors (Lu et al., 2010) indicated also that in rice, maintaining higher $\mathrm{P}$ concentration and $\mathrm{P} / \mathrm{As}$ molar ratio in rice shoot by variety breeding or soil management is one of the means for decreasing arsenic accumulation in rice grain.

\section{CONCLUSIONS}

Arsenic concentrations in wheat samples of the two experiments are higher than those in the plants grown on uncontaminated soil, and, although the daily intake of As calculated in these cases was lower than the daily permissible intake of As $(0.15 \mathrm{mg}$, see Cozzolino et $a l$., 2010 and reference therein), very low possible As intake from others foods (vegetables, meat, fish, eggs and milk) would be enough to increase the daily intake of arsenic above the limit value.

In the experiments showed in this work, it is highlighted the role of $\mathrm{P}$ fertilization in preventing As uptake in wheat plants. These findings could have important implications for human health and agricultural systems, since they suggest that it may limit the ingestion of As through the consumption of crops grown on contaminated soils and reduce yield losses.

\section{ACKNOWLEDGMENTS}

This research was supported by the Italian Research Program of National Interest (PRIN), year 2008. DiSSPAPA Number 229.

\section{REFERENCES}

Abedin, M.J., Cresser, M.S., Meharg, A.A., Feldmann, J., Cotter-Howells, J. 2002. Arsenic accumulation and metabolism in rice (Oryza sativa L.) Environ. Sci. and Technol. 36, 962968.

Adriano, D.C. 2001. Trace Elements in Terrestrial Environments, Springer-Verlag: New York.

ARPAT-UNIFI. 2003. Studio della dispersione dell'arsenico nella Piana di Scarlino (GR). Internal report, Agenzia Regionale per la Protezione dell'Ambiente della Toscana (ARPAT)-Dipartimento di Scienze della Terra Università di Firenze (UNIFI) Convention.

Barrachina, A.C., Carbonell F.B., Beneyto, JM. 1995. Arsenic uptake, distribution, and accumulation in tomato plants - Human health risk. Fresenius Environ. Bull. 4, 395-400.

Brandsetter, A., Lombi, E., Wenzel, A.A., Adriano, D. 2002. Arsenic-contaminated soils: I. Risk assessment. In: Remediation Engineering of Contaminated Soil. New York, pp. 715-737.

Carbonell-Barrachina, A.A., Burlo, F., Burgos-Hernandez, A. and Mataix, J. 1997. The influence of arsenite concentration on arsenic accumulation in tomato and bean plants. Sci. Hort. 71, 167-176.

Costagliola, P., Benvenuti, M., Benvenuti, M.G., Innocenti, A., Mascaro, I., Paolieri, M., Rossato, L., Tanelli, G. 2004. Geogenic and anthropogenic geochemical anomalies of hazardous elements in Southern Tuscany mining districts. In: Proceedings of $32^{\text {nd }}$ International Geological Congress. Florence, 633-634.

Cozzolino, V., Pigna, M., Di Meo V., Caporale A.G., Violante, A., Meharg, A.A. 2010. Influence of phosphate addition on the arsenic uptake by wheat (Triticum durum) grown in arsenic polluted soils. Fresenius Environmental Bulletin 19, 838-845.

Donati, A., Pulselli, F.M., Riccobono, F., Dallai, L., Francovich, R., Tiezzi, E. 2005. Origin of arsenic pollution in southwest Tuscany: comparison of fluvial sediments. Annali di Chimica 95, 161-166. 
Duxbury, J.M., Mayer, A.B., Lauren, J.B. Hassan, N. 2002. Arsenic content of rice in Bangladesh and its impacts on rice productivity. Presented in $4^{\text {th }}$ Annual Conference on arsenic contamination in groundwater in Bangladesh: cause, effect and remedy, Dhaka, Bangladesh.

Geng, C.N., Zhu, Y.G., Hu, Y., Williams, P., Meharg, A.A. 2006. Arsenate causes differential acute toxicity to two P-deprived genotypes of rice seedlings (Oryza sativa L.). Plant Soil 279, 297 306.

Gultz, P.A., Gupta, S., Schulin, R. 2005. Arsenic accumulation of common plants from contaminated soils. Plant Soil 272, 337-347.

Heikens, A. 2006. Arsenic Contamination of Irrigation Water, Soil and Crops in Bangladesh: Risk Implications for Sustainable Agriculture and Food Safety in Asia, Food and Agricultural Organization of the United Nations, Regional Office for Asia and the Pacific.

Liu, X., Zhang, S., Shan, X., Zhu, Y.G. 2005. Toxicity of arsenate and arsenite on germination seedling growth and amylolytic activity of wheat. Chemosphere 61, 293-301.

Lu, Y., Dong, F., Deacon, C., , Chen, H., Raab, A., and Meharg, A. 2010. Arsenic accumulation and phosphorus status in two rice (Oryza sativa L.) cultivars surveyed from fields in South China. Environ. Pollut., doi:10.1016/j.envpol.2009.12.022

Mandal, B.K., Suzuky, K.T. 2002. Arsenic round the world: a review. Talanta 58, 201-235.

Martin, M., Violante., A, Barberis, E. 2007. Fate of arsenite and arsenate in flooded and not flooded soils of southwest Bangladesh irrigated with arsenic contaminated water. J. Environ. Sci. Health A Tox. Hazard Subst. Environ. Eng. 42, 1775-83.

Meharg, A.A. and Macnair, M.R. 1991. The mechanisms of arsenate tolerance in Deschampsia cespitosa (L.) Beauv and Agrostis capillaris L. New Phytol. 119, 291-297.

Meharg, A.A., Macnair M.R. 1992. Suppression of the high affinity phosphate uptake system a mechanism of arsenate tolerance in Holcus lanatus L. Journal of Experimental Botany. 43, 519-524.
Meharg, A.A. 1994. Integrated tolerance mechanisms constitutive and adaptive plant responses to elevated metal concentrations in the environment. Plant Cell Environ. 17, 989-993.

Meharg, A.A. 2005. Mechanism of plant resistance to metal and metalloid ions and potential biotechnological applications. Plant Soil, 274, 163-174.

Norra, S., Berner, Z.A., Agarwala, P., Wagner, F., Chandrasekharam, D., Stuben, D. 2005. Impact of irrigation with As rich groundwater on soil and crops: A geochemical case study in West Bengal Delta Plain, India. Appl. Geochem. 20, 1890-1906.

Paliouris, G., Hutchinson, T.C. 1991. Arsenic, cobalt and nickel tolerances in two populations of Silene vulgaris (Moench) Garcke from Ontario, Canada. New Phytol. 117, 449-459.

Peryea, F.J. 1998. Phosphate starter fertilizer temporarily enhances soil arsenic uptake by apple trees grown under field conditions. Hort. Sci. 33, 826-829.

Pigna, M., Cozzolino, V., Violante, A., Meharg, A.A. 2009. Influence of phosphate on the arsenic uptake by wheat (Triticum durum L.) irrigated with arsenic solutions at three different concentrations. Water Air Soil Pollut. 197, 371380 .

Quaghebeur, M., Rengel, Z. 2003. The distribution of arsenate and arsenite in shoots and roots of Holcus lanatus is influenced by arsenic tolerance and arsenate and phosphate supply. Plant Physiol. 132, 1600-1609

Raghothama, K.G. 1999. Phosphate acquisition Annu. Rev. Plant Physiol. Mol. Biol. 50, 665-93.

Rahman, M.A., Rahman, M.M., Miah, M.A.M., Khaled, H.M. 2004. Influence of soil arsenic concentrations in rice (Oryza sativa L.). J. Subtrop. Agri. Res. Dev. 2, 24-31.

Rahman, M.A., Hasegawa, H., Rahman, M.M., Rahman, M.A., Miah, M.A.M. 2007. Accumulation of arsenic in tissues of rice plant (Oryza sativa L.). Chemosphere 69, 942-948.

Runge-Metzger, A. 1995. Closing the cycle: obstacles to efficient P management for improved global security. In: Tiessen H (ed) Phosphorus in the global environment. Wiley, Chichester, UK, pp. 27-42. 
Smith, E., Naidu, R., Alston, A.M. 1998 Arsenic in the soil environment: a review. Adv. Agron. 64, 149-195.

Sneller, E.F.C., Van Heerwaarden, L.M., Kraaijeveld-Smit, F.J.L., Ten Bookum, W.M., Koevoets, P.L.M., Schat, H., Verkleij, J.A.C. 1999. Toxicity of arsenate in Silene vulgaris, accumulation and degradation of arsenate induced phytochelatins. New Phytol. 144, 223 232.

Soriano, M.A., Fereres, E. 2003. Use of crops for in situ phytoremediation of polluted soils folling a toxic flood from mine spill. Plant Soil 256, 253-264.

Tao, Y., Zhang, S., Yuan, W.J., Shan, X.Q 2006. Effect of oxalate and phosphate on the release of arsenic from contaminated soils and arsenic accumulation in wheat. Chemosphere 65, 1281-1287.

Ullrich-Erebius, C.I., Sanz, A., Novacky, A.J. 1989. Evaluation of arsenate and vanadate associated changes of electrical membrane potential and phosphate transporting Lemma gibba G1. J. Exp. Bot. 40, 119-128.

Violante, A., Pigna, M. 2002. Competitive sorption of arsenate and phosphate on different clay minerals and soils. Soil Sci. Soc. Am. J. 66, 1788-1796.

Wang, L., Duan, G. 2009. Effect of external and internal phosphate status on arsenic toxicity and accumulation in rice seedlings. J. Environ. Sci. $21,346-351$
Wauchope, R.D. 1983. Uptake, translocation and phytotoxicity of arsenic in plants. In: Arsenic: Industrial, Biomedical, Environmental Perspectives. New York, 1983, pp. 348-374.

Williams, P.N., Price, A.H., Raab, A., Hossain, S.A., Feldmann, J., Meharg, A.A. (2005). Variation in arsenic speciation and concentration in paddy rice related to dietary exposure. Environ. Sci. and Technol. 39, 5531-5540.

Williams, P.N., Villana, A., Deacon, C., Raab, A., Figuerola, J., Green, A.J., Feldmann, J., Meharg, A.A. 2007. Greatly enhanced arsenic shoot assimilation in rice leads to elevated grain levels compared to wheat and barley. Environ. Sci. and Technol. 41, 6854-6859.

Wenzel, W.W., Kirchbaumer, N., Prohaska, T., Stingeder, G., Lombi, E., Adriano, D.C. 2001. Arsenic fractionation in soil using an improved sequential extraction procedure. Anal. Chim. Acta 436, 309-323.

Zhao, F.J., Lopez-Bellido, F.J., Gray, C.W., Whalley, W.R., Clark, L.J., McGrath, S.P 2007. Effects of soil compaction and irrigation on the concentrations of selenium and arsenic in wheat grains. Sci. Total Environ. 372, 433-439. 